\title{
Análise da aplicação do princípio da vedação de retrocesso ambiental pelo supremo tribunal federal em julgados de (in)constitucionalidade das áreas rurais consolidadas
}

\author{
Analysis of the application of the environmental non- \\ regression principle by the supreme federal court in \\ judgments of (in)constitutionality of consolidated rural \\ areas
}

iD Eriberto Francisco Bevilaqua Marin ${ }^{1}$

(iD) Giovani Martins De Araújo Mascarenhas²

\begin{abstract}
Resumo: A presente pesquisa adota uma abordagem qualitativa e se desenvolve por meio de análise bibliográfica e documental de decisões e construções doutrinárias, com adoção do método dedutivo para, após a análise da configuração histórica e legal do princípio da vedação do retrocesso em matéria ambiental, compreender e ponderar a aplicação desse princípio pelo Supremo Tribunal Federal, no julgamento das ações diretas de inconstitucionalidades e da ação declaratória de constitucionalidade no que tange à criação das Áreas Rurais Consolidadas pela Lei Florestal $n^{\circ}$ 12.651, de 2012, que dispõe a Lei Florestal brasileira. Nesse contexto, faz-se uma abordagem sobre a evolução e compreensão da questão ambiental no cenário global, de regulação do meio ambiente
\end{abstract}

\footnotetext{
1 Professor Associado IV da Faculdade de Direito da Universidade Federal de Goiás. Doutor em Direito Constitucional pela Faculdade de Direito da Universidade Federal de Minas Gerais. Professor do Programa de Pós-Graduação stricto sensu em Direito Agrário - PPGDA/FD/UFG.

2 Mestre em Direito Agrário pela Universidade Federal de Goiás - PPGDA/FD/UFG. Graduado em direito pela UFG. Advogado inscrito na OAB $n^{\circ} 55.785 / G O$. Pesquisador focado em questões ambientais e alimentares. E-mail: giiovannimascarenhas@ gmail.com.
} 
na Constituição Federal brasileira de 1988, e a criação das Áreas Rurais Consolidadas. Após, analisa-se o princípio da vedação de retrocesso, como garantidor das conquistas ambientais, que visa a assegurar proteção ao meio ambiente, bem como de seu desdobramento no dever de progressividade da proteção, seja pelos órgãos estatais, seja pelos particulares. Verifica-se, ao final, que o STF cita e analisa o princípio em diversas passagens no acórdão, contudo sem a sua efetiva aplicação, de forma que se conclui que houve uma aplicação incorreta do princípio da vedação de retrocesso ambiental pelo Supremo Tribunal Federal no caso da Lei n. ${ }^{\circ} 12.651 / 2012$.

Palavras-chave: Direito Agrário. Princípio da Vedação de Retrocesso. Lei Florestal. Controle de constitucionalidade. Supremo Tribunal Federal.

\begin{abstract}
The present research adopts a qualitative approach and is developed through bibliographic and documentary analysis of doctrinal decisions and constructions, with the adoption of the deductive method so that, after analyzing the historical and legal configuration of the principle of prohibition of the setback in environmental matters, it is possible to understand and consider the application of this principle by the Supreme Federal Court, in the judgment of the direct actions of unconstitutionalities and the declaratory action of constitutionality with respect to the creation of the Consolidated Rural Areas by the Forest Law No. 12,651, of 2012, which provides for the Brazilian Forest Law. In this context, an approach is made about the evolution and understanding of the environmental issue in the global scenario, of environmental regulation in the Brazilian Federal Constitution of 1988, and the creation of the Consolidated Rural Areas. Afterwards, the principle of prohibition of setbacks is analyzed, as guarantor of the environmental conquests, which aims to ensure protection to the environment, as well as its unfolding in the duty of progressive protection, either by state agencies or by private individuals. At the end, it appears that the STF quotes and analyzes the principle in several passages in the judgment, however without its effective application. In that way, it is concluded that there was an incorrect application of the principle of prohibition of environmental
\end{abstract}


retrogression by the Supreme Federal Court in case of Law No. 12,651 / 2012.

KeyWords: Agrarian Law. Principle of non-regression. Forest Law. Constitutionality control. Federal Court of Justice.

Data de submissão do artigo: Agosto de 2020

Data de aceite do artigo: Fevereiro de 2021 
Análise da aplicação do princípio da vedação de retrocesso ambiental pelo supremo tribunal... Eriberto Francisco Bevilaqua Marin • Giovani Martins De Araújo Mascarenhas

\section{Introdução}

A pesquisa insere-se em um contexto brasileiro de instabilidade político-jurídica e crise de credibilidade de suas instituições representativas, motivo pelo qual se torna ainda mais importante a observância aos princípios que visam à vedação ao retrocesso e de proteção de áreas ambientais. Especialmente relevantes, nessa situação, são as áreas merecedoras, por determinação legal, de uma proteção ambiental diferenciada.

A extinção de recursos naturais, poluição, danos graves e irreversíveis à natureza, dentre outras evidências empíricas, desde as décadas de 1950 e 1960, trazem à tona a preocupação com a proteção ambiental em equilíbrio com o desenvolvimento. $O$ desenvolvimento e a proteção ambiental, em tese, podem ser considerados conflitantes, ou, em certos casos, configurar um aparente conflito. A concepção de um desenvolvimento sustentável, embasada na relação de interdependência e a preocupação de um desenvolvimento com a proteção ao meio ambiente têm sido objeto de relevantes debates e reflexões pela academia e sociedade internacional, motivo pelo qual o crescimento econômico sem a devida preocupação social e ambiental consiste em ameaça às futuras gerações, bem como à sobrevivência da espécie humana.

Em razão dos graves problemas ambientais revelados nas últimas décadas em todo o planeta, houve, desde a Declaração de Estocolmo de 1972, um aumento no empenho dos países em editarem normas de proteção ao meio ambiente. A proteção à natureza visa a tutelar o ser humano, já que o meio ambiente saudável é item essencial para que seja possível uma existência humana digna (arts. $1^{\circ}$, III, e 225, da Constituição Federal de 1988). Nesse sentido, o desenvolvimento sustentável tem se fundamentado em concepção antropocêntrica de garantia das necessidades humanas em detrimento da proteção ambiental. Em novo viés, insere-se o princípio de vedação ao retrocesso ambiental, como garantia de sua proteção e sustentabilidade. Com efeito, sobressai-se a aná- 
Análise da aplicação do princípio da vedação de retrocesso ambiental pelo supremo tribunal... Eriberto Francisco Bevilaqua Marin • Giovani Martins De Araújo Mascarenhas

lise do princípio da vedação de retrocesso, tendo em vista que a proteção ambiental já alcançada não pode ser perdida ou sofrer mitigação pela edição de uma norma ou de políticas públicas que venham a diminuir o grau de concretização da proteção ambiental já alcançada.

A instituição da Lei Florestal brasileira, por meio da Lei n. ${ }^{\circ}$ 12.651, de 25 de maio de 2012, deu origem a várias críticas relacionadas à redução da proteção ambiental em comparação ao revogado Código Florestal de 1965, o que poderia constituir uma ofensa ao princípio da vedação de retrocesso ambiental. Em face de disposições da nova Lei Florestal, foram interpostas cinco ações típicas da fiscalização abstrata de normas de competência originária do Plenário do Supremo Tribunal Federal, sendo uma ação declaratória de constitucionalidade (ADC 42/DF); e quatro ações diretas de inconstitucionalidade (ADIs 4.901/DF; 4.902/DF; 4.903/DF; e 4.937/DF). Em relatório comum do Ministro Luiz Fux, o Tribunal Pleno decidiu parcialmente procedentes as referidas ações, em 28 de fevereiro de 2018, cuja ementa refere-se pela "inviabilização de alegação de 'vedação ao retrocesso"' (STF - Pleno, ADC 42/DF, Divulgação: 12/08/2019; Publicação Dje-175 13/08/2019).

Uma das principais alterações promovidas pela Lei n. ${ }^{\circ}$ 12.651/2012 na Lei n. ${ }^{\circ}$ 4.771/1965, até então vigente, foi a criação das Áreas Rurais Consolidadas. Essas áreas são frações de terreno inseridas em Áreas de Preservação Permanente (que não admitiriam desmatamento ou utilização antrópica de supressão de vegetação) e que foram ilegalmente desmatadas. As Áreas Rurais Consolidadas permitem, então, a manutenção de atividades agrossilvipastoris, de ecoturismo e de turismo rural em áreas que tiveram suas vegetações suprimidas, ilegalmente, em data anterior a 22 de julho de 2008 (Art. 61-A, Lei n. ${ }^{\circ} 12.651 / 2012$ ).

O debate acerca da criação das Áreas Rurais Consolidadas gira em torno do princípio da vedação ao retrocesso, ao passo que a autorização, por legislação superveniente, de continuidade de atividades que jamais poderiam ter sido iniciadas em Áreas de Preservação Permanente (pela redação até então vigente, da Lei 
Análise da aplicação do princípio da vedação de retrocesso ambiental pelo supremo tribunal... Eriberto Francisco Bevilaqua Marin • Giovani Martins De Araújo Mascarenhas

n. ${ }^{4}$ 4.771/1965) poderia significar um retrocesso na proteção ambiental conferida pela legislação.

Inserida nesse contexto, a presente pesquisa adota uma abordagem qualitativa e se desenvolve por meio de análise bibliográfica e documental, com adoção do método dedutivo para, após a análise da configuração histórica e legal do princípio da vedação do retrocesso em matéria ambiental, compreender e ponderar a aplicação desse princípio pelo Supremo Tribunal Federal no que tange à criação das Áreas Rurais Consolidadas pela Lei Florestal $n^{\circ}$ 12.651, de 2012.

Dessa forma, busca-se uma compreensão crítica-discursiva da literatura, com o propósito de realizar uma análise sobre a decisão do Supremo Tribunal Federal, sob a perspectiva de sua fundamentação e aplicação do princípio de vedação do retrocesso ambiental, em face da regulação das Áreas Rurais Consolidadas pela Lei $n^{\circ}$ 12.651, de 2012. Nesse sentido, o estudo intenta verificar se a observância ou não ao princípio da vedação do retrocesso evidencia uma concepção sobre a tutela do meio ambiente em face do desenvolvimento sustentável.

Nesse desiderato, em primeiro tópico, analisa-se o desenvolvimento da compreensão sobre o meio ambiente no contexto global com aportes teóricos do utilitarismo até a proteção integrada. Em seguida, aborda-se a regulação ambiental na Constituição Federal de 1988 e aspectos sobre a posterior regulação infraconstitucional de matérias ambientais no Direito brasileiro. Em terceiro tópico, como aspecto central da pesquisa, busca-se verificar a afirmação do princípio da proibição de retrocesso ambiental nos planos normativo e jurisprudencial. Ao apresentar o princípio da vedação de retrocesso, discorre-se sobre sua importância e aplicabilidade para a proteção do meio ambiente e, por conseguinte, de todas as formas de vida. Por fim, faz-se uma breve análise acerca da aplicação do mencionado princípio e de seus fundamentos na decisão proferida pelo Supremo Tribunal Federal, nas ações de (in) constitucionalidade propostas em face da Lei Florestal brasileira 
Análise da aplicação do princípio da vedação de retrocesso ambiental pelo supremo tribunal... Eriberto Francisco Bevilaqua Marin • Giovani Martins De Araújo Mascarenhas

vigente, especialmente sobre as Áreas Rurais Consolidadas (arts. $59,60$ e $61-A)$.

\section{O meio ambiente no cenário global: do utilitarismo à proteção integrada}

O ser humano, desde a sua origem, intervém no planeta e, com isso, tem alterado o seu habitat visando à adequação às suas necessidades de sobrevivência, segurança, estabilidade, consumo e conforto. Nos últimos tempos, os humanos, aglomerados em estados-nações, caminhavam em busca de progresso social, bélico, tecnológico e, precipuamente, econômico. Para tanto, possuíam o amparo de uma visão mecanicista, de interpretação do mundo como um conjunto de elementos dissociados.

Após o fim do século XIX, contudo, surgiram grandes inovações em relação aos transportes, organização social e produção, inclusive com o advento da industrialização. $O$ enorme e súbito aumento da produção, no decorrer do século XX, viabilizado e caracterizado pelas três grandes revoluções industriais (máquina a vapor; metalúrgica, siderúrgica e química; e tecnológica), demonstrou como a esfera econômica passou a interferir ativa e sensivelmente no meio ambiente e na natureza, o que resultou no inevitável surgimento de diversas consequências que afetaram também o ser humano (LEITE, 2011, p. 5).

Com o início da percepção dos efeitos negativos da visão mecanicista, por meio da qual se acreditava que a interferência do ser humano na natureza teria seus efeitos restritos ao seu ambiente (que, por sua vez, só existiria para satisfazer as necessidades humanas), evidenciou-se que os recursos naturais, apesar de abundantes, não seriam capazes de acompanhar o ritmo da produção (ARAÚJO, 2008, p.18). Por esse motivo, a questão ambiental ressurge em nova perspectiva com o reconhecimento de que, ao contrário do que se imaginava, a priori, apesar de abundantes, os recursos naturais são limitados e finitos. 
Análise da aplicação do princípio da vedação de retrocesso ambiental pelo supremo tribunal... Eriberto Francisco Bevilaqua Marin • Giovani Martins De Araújo Mascarenhas

A realidade da escassez e finitude dos recursos foram confrontadas com as ações e concepções que entendiam a natureza como meio para se atingir o progresso/desenvolvimento (fim). Esse confronto entre a realidade e o pensamento utilitarista, da natureza, como forma de se obter o maior benefício com o menor investimento e no mais curto prazo possível, resultou no surgimento de inúmeros problemas para a própria humanidade. Como observam Ingo Sarlet e Thiago Fensterseifer (2013, p. 33), "a questão nuclear, a destruição incessante das florestas tropicais, a poluição dos rios e oceanos, a poluição atmosférica - especialmente nos grandes centros urbanos -, entre tantas outras formas de desequilíbrio ecológico que comprometem sobremaneira o bem-estar e a qualidade de vida individual e coletiva".

Nessa situação, salienta-se que não apenas os humanos interferem no meio ambiente, mas também o ambiente exerce uma enorme influência na humanidade, e isso interfere na qualidade de vida humana, além da sua própria capacidade de existência e manutenção. Esse pensamento é explorado sobretudo a partir da "ecologização do pensamento" de Edgar Morin (2002), que destaca a dependência do ser humano tanto do sistema ao qual pertence, quanto do ambiente ao qual está inserido. Nesse horizonte, analisa Morin (2002, p. 254) que "a organização ativa e o ambiente são, sempre se mantendo distintos um do outro, um no outro, cada um à sua maneira, e suas indissociáveis interações e relações mútuas complementares, concorrentes e antagônicas". Para o autor (2002, p. 254), “o ambiente ao mesmo tempo alimenta e ameaça, faz existir e destrói. A própria organização transforma, polui, enriquece. Um círculo retroativo fenomenal vai unir o ser vivo a seu ecossistema, um produzindo o outro reciprocamente".

Nessa acepção, a importância de uma relação adequada entre o ser humano e o ambiente, de uma parte, e de todos os sistemas que compõem o sistema global, de outra parte, não se restringe às fronteiras e às distâncias geográficas. Isso porque todos os elementos-partes de um mesmo sistema global estão integrados e são igualmente responsáveis pela manutenção dessa relação. 
Análise da aplicação do princípio da vedação de retrocesso ambiental pelo supremo tribunal... Eriberto Francisco Bevilaqua Marin • Giovani Martins De Araújo Mascarenhas

Nesse contexto, José Joaquim Gomes Canotilho (2004, p. 5) declara a imperatividade de se formular um ordenamento jurídico-político que transcenda o conceito de estados e nações, para efetivamente possibilitar a proteção ambiental.

O aspecto apontado por Canotilho $(2004$, p. 5) é resultado de um desenvolvimento cultural que expôs a íntima integração dos elementos que compõem o meio ambiente. Trata-se da indissociabilidade desses elementos e da impossibilidade de limitar a importância da proteção ambiental a determinados espaços geográficos. A compreensão de que o pensamento utilitarista apresenta grandes incongruências faz com que esse tipo de pensamento seja sobreposto para dar lugar, no cenário internacional, à busca pela proteção jurídica integrada do meio ambiente.

A metade do século XX foi marcada pela ascensão do Direito transnacional, inclusive idealizado para conferir ao meio ambiente a proteção necessária. Após o final da Segunda Guerra Mundial (1939-1945), em um contexto histórico de grandes mudanças, a comunidade internacional voltou sua atenção para a importância de tutelar os direitos humanos fundamentais que, até então, eram ignorados ou desrespeitados. Dentre os quais, o direito difuso ao meio ambiente. Como resultado dessa conquista, realizou-se, em 1972, em Estocolmo, na Suécia, a Conferência das Nações Unidas sobre o Ambiente Humano, onde foram discutidas e abordadas novas formas de desenvolvimento. Nessa oportunidade, foi criado o termo "ecodesenvolvimento", que precedeu às expressões "desenvolvimento sustentável" ou "economia verde", adotadas atualmente (ARAÚJO, 2008, p. 24; BRIGTHON, 2016, p. 223).

A Conferência de Estocolmo foi pautada pelos posicionamentos dicotômicos apresentados pelos países desenvolvidos e em desenvolvimento no que se refere às formas propostas para lidar com a questão ambiental. Essa situação deu-se pelo fato de que, de um lado, o grupo dos países desenvolvidos, que já convivia diretamente com as consequências do processo de degradação ambiental, propôs zerar o Produto Interno Bruto (PIB) como solução à problemática ambiental; e o segundo grupo, por outro 
Análise da aplicação do princípio da vedação de retrocesso ambiental pelo supremo tribunal... Eriberto Francisco Bevilaqua Marin • Giovani Martins De Araújo Mascarenhas

lado,preocupava-se em alcançar o patamar de desenvolvimento atingido pelo "mundo desenvolvido", como forma de diminuição da pobreza, numa proposta conhecida como "desenvolvimentismo" (GRANZIERA, 2011, p. 36).

Em 1987, surge na Comissão Mundial sobre Meio Ambiente e Desenvolvimento, criada pela ONU (1983), a definição mais aceita de "desenvolvimento sustentável", que foi caracterizado como o "modelo capaz de suprir as demandas da geração atual, sem impedir a capacidade de atender às necessidades das gerações futuras" (ARAÚjO, 2008, p. 29). O Relatório Brundtland, intitulado "Nosso Futuro Comum", publicado em 1987, não só deu origem ao termo desenvolvimento sustentável, como ainda propôs a integração da questão ambiental ao desenvolvimento econômico, sugerindo uma nova forma de progresso da sociedade (GRANZIERA, 2011, p. 44).

Anos mais tarde, em 1992, foi realizada na cidade do Rio de Janeiro (Brasil), a Conferência das Nações Unidas sobre Meio Ambiente e Desenvolvimento, também denominada RIO-92 ou ECO92, que teve como principal resultado a solidificação da ideia de desenvolvimento sustentável com a propositura de um modelo de crescimento econômico menos consumista. Como fruto dessa conferência, foram aprovados diversos textos, dentre os quais merecem destaque a Declaração do Rio, a Convenção-Quadro de Mudanças Climáticas, e a Convenção-Quadro sobre a Diversidade Biológica e a Agenda 21. A Agenda 21 foi considerada o documento mais importante da conferência, por constituir um programa de ações que buscavam viabilizar o desenvolvimento sustentável (GRANZIERA, 2011, p. 45-52).

Na Conferência Mundial sobre Desenvolvimento Sustentável, sediada na cidade de Johannesburgo (África do Sul), em 2002 (mais conhecida como Rio+10), foi analisado o progresso dos acordos elaborados na Rio-92, à luz da Agenda 21, com o objetivo de verificar o que fora feito até então e renovar os compromissos firmados naquela oportunidade, além de incluir na temática ambiental os aspectos sociais, com temas relativos à erradicação da pobreza e a afirmação da qualidade de vida. A Conferência de Johanesburgo 
Análise da aplicação do princípio da vedação de retrocesso ambiental pelo supremo tribunal... Eriberto Francisco Bevilaqua Marin • Giovani Martins De Araújo Mascarenhas

representou, todavia, "significativo desvio na rota em relação ao modelo das Conferências anteriores da ONU" (CRETELLA NETO, 2012, p. 175). De fato, observa-se que a maioria dos países tentou defender seus interesses de cunho econômico e, com isso, a Conferência Rio+10 se findou sem apresentação de qualquer proposta efetiva de proteção ambiental.

A Conferência das Nações Unidas sobre o Desenvolvimento Sustentável (conhecida como Rio+20) realizada em 2012, no Rio de Janeiro, voltou a analisar dois importantes temas, que já eram recorrentes, sobre a economia verde na perspectiva do desenvolvimento sustentável e erradicação da pobreza e a estrutura institucional para o desenvolvimento sustentável. A conferência, todavia, não obteve os resultados esperados, sobretudo em função da dicotomia dos interesses dos países desenvolvidos e em desenvolvimento e da crise econômica que assolava o mundo. $O$ documento final, denominado "O Futuro que Queremos", limitou-se ao arrolamento de intenções e a reafirmar os compromissos anteriores, de forma a relegar para os anos vindouros a definição de medidas práticas para garantir a proteção do meio ambiente (CNUDS, 2012).

É certo que os debates internacionais acerca da proteção conferida ao meio ambiente se desenvolveram permeados de posições divergentes e compreensões contrastantes acerca das contribuições de cada país para mitigar as mudanças climáticas. Em face das diferentes realidades das nações evidencia-se inclusive a dificuldade de compreensão da ecologia em realidades diferentes, ao ponto de a comissão Brundtlant (1987) difundir o entendimento de que a pobreza seria tão ou mais responsável pela degradação ambiental que a riqueza - sendo tal compreensão explicada pela não-adoção do mesmo parâmetro de "eco-management tecnocrático internacional" utilizado nos países do norte global (ALIER, 1997, p. 10).

Apesar das diferentes realidades, deve-se frisar que a discussão acerca da proteção conferida ao meio ambiente se insere em uma realidade capitalista de busca por avanços econômicos, inde- 
Análise da aplicação do princípio da vedação de retrocesso ambiental pelo supremo tribunal... Eriberto Francisco Bevilaqua Marin • Giovani Martins De Araújo Mascarenhas

pendentemente do nível já alcançado de desenvolvimento econômico por cada Nação. Nesse sentido, destacam-se as ponderações de Juan Martinez Alier, que frisa que o mercado impõe uma busca de ganhos "Mas o mercado não garante que a economia se encaixe na ecologia, já que o mercado sub-valoriza as necessidades futuras e não conta os prejuízos externos às transações mercantis" (ALIER, 1997, p. 8).

Foi nesse cenário, de poucas ações e avanços, e de preocupação com a orientação econômica visivelmente sobrepondo-se à importância dada à proteção ambiental, que se destaca o princípio da vedação de retrocesso ambiental. Esse princípio foi inserido, pela primeira vez em contexto transnacional, no documento $O$ Futuro que Queremos, em seu ponto $20^{3}$.

O princípio de não retrocesso, defendido e desenvolvido por Michel Prieur, é um princípio inerente à proteção dos direitos humanos e de garantia do direito ao meio ambiente. A afirmação de não retrocesso na seara ambiental corresponde às exigências internacionais da proteção ao meio ambiente e lhe confere um nível cada vez mais elevado de proteção, dentro de uma visão de equilíbrio com as atividades humanas (PRIEUR, 2011, p.79).

O direito ao meio ambiente, fruto de tantas alterações, é classificado por Robert Alexy (2008) como um direito "fundamental completo", um direito fundamental "como um todo", tendo em vista que abrange um leque de direitos pragmáticos e teóricos para sua concretização (como o direito de defesa, direito a proteção e direito a determinados procedimentos). Desse modo, a vedação de retrocesso seria aplicável a todo direito "fundamental completo", com tudo aquilo que Ihe compõe. Esse direito fundamental seria, então, alçado ao patamar de princípio, que o autor classifica como "mandamento de otimização". Como normas, os princípios/ mandamentos de otimização devem ser aplicados na maior me-

\footnotetext{
3 “20. Reconhecemos que desde 1992, a integração das três dimensões do desenvolvimento sustentável tem progredido de forma desigual e sofrido com retrocessos, agravados por várias crises financeiras, econômicas, alimentares e energéticas, que têm desafiado a capacidade de todos os países, em particular dos países em desenvolvimento, de realizar o desenvolvimento sustentável. Nesse sentido, é fundamental não recuar diante dos compromissos firmados na Rio92. Reconhecemos também que as consequências das múltiplas crises que afetam o mundo de hoje são um dos principais problemas que todos os países devem enfrentar, principalmente os países em desenvolvimento".
} 
Análise da aplicação do princípio da vedação de retrocesso ambiental pelo supremo tribunal... Eriberto Francisco Bevilaqua Marin • Giovani Martins De Araújo Mascarenhas

dida possível, de acordo com as possibilidades fáticas e jurídicas do caso concreto. $O$ direito ao meio ambiente, como princípio, se comunica com o princípio da vedação de retrocesso exposto por Prieur (2011).

Com efeito, o princípio da vedação de retrocesso ambiental prima por tutelar que a proteção ambiental já alcançada não pode ser perdida ou sofrer mitigação (retrocesso) pela edição de uma norma ou políticas públicas que venham a diminuir o grau de concretização da proteção ambiental já alcançada.

\section{Constituição de 1988 e criação das Áreas Rurais Consolidadas pela Lei Florestal de 2012}

O Direito ambiental, no panorama jurídico internacional, passou por um processo de intensas modificações, sendo-lhe conferida, gradativamente, umamaior importância. No âmbito jurídico brasileiro, a realidade não é diferente. No plano constitucional, o avanço se deu com a Constituição Federal de 1988, que assegura, como um direito fundamental, o acesso ao meio ambiente sadio à existência digna para as futuras gerações. A sua promulgação em 5 de outubro de 1988 insere-se no cenário de crise de recursos naturais pelos efeitos de sua exploração desenfreada e de pressão internacional de tutela jurídico-constitucional do meio ambiente.

Não obstante introduzir, ao longo de seu texto, diversos dispositivos relacionados à questão ambiental, a Constituição de 1988 dispõe de um capítulo, inserido no título da "ordem social", sobre a proteção ao meio ambiente. Em seu art. 225, a Constituição estabelece diversos direitos e deveres concernentes ao meio ambiente, e demonstra que é visto como um todo e não como a simples soma de seus componentes (característica do pensamento da proteção integrada). O meio ambiente ecologicamente equilibrado, bem de uso comum do povo e essencial à sadia qualidade de vida, foi regulado como direito de todos, sendo que foi imposto ao Poder 
Análise da aplicação do princípio da vedação de retrocesso ambiental pelo supremo tribunal... Eriberto Francisco Bevilaqua Marin • Giovani Martins De Araújo Mascarenhas

Público e à coletividade o dever de defendê-lo e preservá-lo para as presentes e futuras gerações.

Na ocasião, com o advento da Constituição de 1988, o âmbito legislativo infraconstitucional brasileiro passou a ser, cada vez mais, permeado por leis que buscam efetivar a garantia ao meio ambiente ecologicamente equilibrado (SARLET; FENSTERSEIFER, 2013, p. 29).

O grande rol de direitos e deveres regulados por toda a legislação é contraposto com a falta de efetividade de muitas dessas leis, conforme ressalta Luciane Martins de Araújo (2013, p. 139), que observa que o cenário político e econômico do Brasil direciona-se de forma a permitir a flexibilização "da legislação ambiental já consolidada, desconstruindo a proteção ambiental conquistada no decorrer dos anos". O cenário de desregulamentação do qual trata a autora é relacionado à pressão de mercado em busca de maximização de lucros, que, conforme a observação de Alier (1997, p. 9), "sub-valoriza as necessidades futuras e não conta os prejuízos externos às transações mercantis".

A pressão de mercado sobre a legislação ambiental brasileira, seja pela sua flexibilização, seja pela sua inaplicação, é principalmente atrelada a atividades extrativistas (agricultura, pecuária, mineração e extração de madeiras). Trata-se de um mercado globalizado no qual os produtos das atividades extrativas tornam-se commodities e, assim, se submetem principalmente às bolsas de mercadorias e aos monopólios mundiais, e não às necessidades humanas (OLIVEIRA, 2009, p.6).

No mesmo sentido das pressões por flexibilização da legislação, inserem-se também as pressões pela inaplicação de legislações vistas como entraves ao desenvolvimento da atividade econômica. O Código Florestal de 1965, antes de ser substituído pela Lei Florestal, instituída pela Lei n. ${ }^{\circ} 12.651$, de 25 de maio de 2012 , foi marcado exatamente pela inefetividade. O desrespeito à impossibilidade de supressão de vegetação e utilização de Áreas de Preservação Permanente serviu como base posterior para con- 
Análise da aplicação do princípio da vedação de retrocesso ambiental pelo supremo tribunal... Eriberto Francisco Bevilaqua Marin • Giovani Martins De Araújo Mascarenhas

solidar a flexibilização da antiga legislação, inclusive com a criação das mencionadas Áreas Rurais Consolidadas.

Dentre as inovações dessa Lei Florestal (n 12.651/2012), trazidas em relação ao código anterior, de 1965, encontra-se a criação do instituto das Áreas Rurais Consolidadas, que afetou sensivelmente as Áreas de Preservação Permanente (APPs) e as Reservas Legais (RL) ${ }^{4}$. Nesse aspecto, a criação das Áreas Rurais Consolidadas mitigou a obrigação de preservação da vegetação presente nas áreas de proteção permanente e reservas legais, com fundamento em atos que teriam sido realizados já em desconformidade com o Código Florestal anterior (Lei n. ${ }^{\circ}$ 4.771/1965).

As Áreas Rurais Consolidadas, definidas pelo inciso IV do art. $3^{\circ}$ da nova Lei Florestal, são áreas de imóvel rural "com ocupação antrópica preexistente a 22 de julho de 2008, com edificações, benfeitorias ou atividades agrossilvipastoris, admitida, neste último caso, a adoção do regime de pousio" (BRASIL, 2012). Assim, as áreas desmatadas em data anterior a 22 de julho de 2008, em desacordo com o antigo Código Florestal, inseridas em Área de Preservação Permanente ou Reserva Legal, podem continuar sendo utilizadas sem a obrigação de recomposição, desde que o proprietário ou posseiro faça sua inscrição no Cadastro Ambiental Rural (CAR) e sua adesão ao Programa de Regularização Ambiental (PRA), conforme estabelecido no art. 59 da referida Lei Florestal de 2012.

As Reservas Legais e as Áreas de Proteção Permanente, flexibilizadas pela nova Lei Florestal, constituem áreas cuja preservação deve ser garantida pelo proprietário ou possuidor da terra, em observância às ideias de proteção ambiental. Passa-se, portanto, pela necessidade de que a produção seja feita de forma a garantir a perpetuação dos recursos, de modo que sejam protegidas não apenas as áreas verdes, mas toda sua influência no meio ambien-

\footnotetext{
4 As Áreas de Preservação Permanente são áreas que devem ser permanentemente protegidas pela sua importância dentro de uma determinada região. Trata-se da proteção conferida à vegetação de áreas costeiras, a matas ciliares e outras áreas que têm importante papel para manutenção de um equilíbrio dentro da região onde se situam. Por outro lado, as Reservas Legais são áreas protegidas dentro de propriedades rurais, calculadas como um percentual da área total da propriedade, que deve ser protegida a fim de garantira a preservação do meio ambiente, que é um dos pilares da função social da propriedade rural, conforme previsão do artigo 186 da Constituição Federal.
} 
Análise da aplicação do princípio da vedação de retrocesso ambiental pelo supremo tribunal... Eriberto Francisco Bevilaqua Marin • Giovani Martins De Araújo Mascarenhas

te, nos cursos hídricos e nascentes, na fauna e flora, bem como nas trocas gasosas e tudo o que envolve o planeta (TRENNEPOHL, 2010, p. 238).

Quando da discussão que precedeu a Lei Florestal de 2012, o que se esperava era uma efetiva atuação do legislador para definir os moldes e formas segundo as quais a recuperação dessas áreas, merecedoras de algum tipo de preservação especial, já eventualmente desmatadas, deveria ser realizada. Não foi, contudo, o que ocorreu. A nova Lei Florestal, apesar de não trazer mudanças significativas acerca das Áreas de Preservação Permanente ou de Reserva Legal, mitigou drasticamente esses institutos ao criar as Áreas Rurais Consolidadas.

A Lei Florestal autoriza, com a criação das Áreas Rurais Consolidadas, a continuidade da exploração de Áreas de Preservação Permanente que se encontravam utilizadas em atividades agrossilvipastoris, de ecoturismo e de turismo rural até 22 de julho de 2008 (art. 61-A da Lei n. ${ }^{\circ}$ 12.651/2012), além de permitir a regularização do produtor rural que mantinha reserva legal inferior àqueles percentuais determinados por lei, por meio de medidas brandas e dificilmente protetivas.

Paulo Affonso Leme Machado (2012, p. 21) observa que a criação das Áreas Rurais Consolidadas foi o produto da incapacidade do poder público de conferir aplicabilidade e efetividade às normas vigentes. Sem planos palpáveis para garantir a recuperação das áreas verdes já devastadas, anistiou-se o desflorestamento por meio da instituição das Áreas Rurais Consolidadas, o que, para Machado (2012, p. 21), configura "uma compensação atentatória ao direito contra o direito ao meio ambiente ecologicamente equilibrado (art. 225 da CF)".

As consequências geradas pelo aumento do desmatamento e de não preservação de áreas verdes estendem-se para além do acréscimo de áreas cultiváveis comemoradas pelos produtores agrícolas e pecuaristas, pela simples razão de que a redução da vegetação influencia diretamente na captação de águas, nas chuvas, 
Análise da aplicação do princípio da vedação de retrocesso ambiental pelo supremo tribunal... Eriberto Francisco Bevilaqua Marin • Giovani Martins De Araújo Mascarenhas

nos cursos d'água e, por conseguinte, afetam a capacidade produtiva das propriedades rurais de um estado, região, ou até mesmo, de todo o país. Luciane Martins de Araújo (2013, p. 141) destaca as consequências negativas ao meio ambiente e à população, provenientes dessa legislação, pois "a grande preocupação com as disposições da nova Lei Florestal é que ela acabe propiciando o aumento do desmatamento, o que contribui para o aumento das emissões de gases de efeito estufa e de consequência, aumento da vulnerabilidade climática". Acrescenta ainda que "a redução das áreas de vegetação nativa, principalmente nas APPs em torno dos cursos d'água, resulta diretamente na redução da quantidade de água, o que afeta diretamente todo o processo produtivo nacional, seja no campo, seja nas cidades, o que afeta também o desenvolvimento almejado" (ARAÚJO, 2013, p. 141).

A evolução histórica de intensificação da preocupação ambiental estagnou-se, ao passo que encontrou como barreira a sobreposição de um dos elementos do desenvolvimento sustentável (o econômico) sobre os demais (social e ambiental). Nesse contexto, encontra-se a importância de resguardar as conquistas normativas concernentes à proteção ambiental, sendo, inclusive, objeto de efetividade do princípio da vedação ao retrocesso.

\section{A afirmação do princípio da proibição de retrocesso ambiental no plano normativo e jurisprudencial}

No quadro de ampliação dos direitos fundamentais, assinalado pela Constituição Federal de 1988, os direitos relativos ao meio ambiente alcançaram patamar de direito fundamental, por meio da garantia constitucional ao meio ambiente ecologicamente equilibrado. A sua consolidação visa a salvaguardar a dignidade da pessoa humana (art. $1^{\circ}, \mathrm{III}, \mathrm{CF} / 88$ ), que impõe a necessidade de não se retroceder naquilo que já foi alcançado. Em linhas gerais, como afirmam Ingo Sarlet e Tiago Fensterseifer (2013, p. 287), "a 
Análise da aplicação do princípio da vedação de retrocesso ambiental pelo supremo tribunal... Eriberto Francisco Bevilaqua Marin • Giovani Martins De Araújo Mascarenhas

humanidade caminha na perspectiva de ampliação da salvaguarda da dignidade da pessoa humana, conformando a ideia de um 'patrimônio político-jurídico' consolidado ao longo do seu percurso histórico-civilizatório, para aquém do qual não se deve retroceder".

O princípio da vedação de retrocesso constitui importante garantia dos direitos adquiridos e funciona como limitador dos poderes legislativo e deliberativo, inerentes ao poder público. A compreensão da proibição de retrocesso, consoante aduzem Ingo Sarlet e Tiago Fensterseifer (2013, p. 293), expressa-se pela garantia dos direitos fundamentais, uma vez que a tutela e o exercício efetivo desses direitos somente é possível onde esteja assegurado um nível mínimo de segurança jurídica e previsibilidade do próprio ordenamento jurídico objetivo.

Esse importante princípio encontra respaldo constitucional, implicitamente, na sistemática de proteção ambiental criada pela Constituição de 1988, de forma que se faz indissociável a tantas garantias previstas. Nessa linha, Ingo Sarlet e Tiago Fensterseifer (2013, p. 288) apontam que a proibição de retrocesso consiste em um princípio constitucional implícito, já consolidado na doutrina, tendo como fundamentos jurídico-constitucionais mais relevantes, entre outros, os princípios do Estado democrático e social de Direito, da dignidade da pessoa humana, da máxima eficácia e efetividade das normas definidoras de direitos fundamentais, da segurança jurídica e seus desdobramentos, bem como do dever de progressividade em matéria de direitos sociais, econômicos, culturais e ambientais.

A vedação de retrocesso em matéria ambiental alcança patamar de cláusula pétrea, inalterável, em conformidade com o disposto no $\S 4^{\circ}$ do art. 60 da Constituição Federal de 1988, que prevê os direitos e garantias individuais e, dentre os quais, figura o direito ao meio ambiente ecologicamente equilibrado. O princípio da não regressão, conforme lição de Paulo Affonso Leme Machado (2017, p. 142-3), "significa que a legislação e a regulamentação relativas ao meio ambiente só podem ser melhoradas e não pioradas". Para o autor, o princípio é matéria de direito individual e constitui uma 
Análise da aplicação do princípio da vedação de retrocesso ambiental pelo supremo tribunal... Eriberto Francisco Bevilaqua Marin • Giovani Martins De Araújo Mascarenhas

cláusula pétrea, "pois é da essência dos direitos humanos que estes mereçam somente evoluir e não regredir".

O princípio da vedação de retrocesso, entretanto, não se limita a ser um instituto implícito do texto constitucional. Trata-se, em verdade, de norma principiológica, por meio da qual se deve observar a legislação e a regulamentação específica em questões ambientais, que compõem, inclusive, documentos e tratados internacionais, dos quais se destacam o documento final da Conferência Rio+20 e o Estatuto do Rio Uruguai (MACHADO, 2017, p. 143-4).

Como princípio normativo e vinculante que é, faz-se necessária a observância de critérios suplementares, por meio dos quais se torna possível verificar se eventuais medidas que impliquem na supressão ou restrição de direitos fundamentais podem, efetivamente, ser entendidas como retrógradas. Para tanto, com o escopo de aferir eventual violação ao princípio de não retrocesso, devem-se utilizar fundamentos e critérios que ultrapassam o próprio princípio, referentes à proteção da confiança, da dignidade da pessoa humana e do correlato mínimo existencial (social e socioambiental) do núcleo de direitos fundamentais, conforme afirmam Ingo Sarlet e Tiago Fensterseifer (2013).

O critério do mínimo existencial constitui limitação à cláusula da reserva do possível e impõe que o Estado deve levar em conta o máximo de recursos disponíveis para cumprir com os objetivos de tutela socioambiental. Não se apresenta adequado, então, utilizar-se da reserva do possível como barreira à realização do núcleo mínimo dos direitos sociais, denominado mínimo existencial socioambiental (FENSTERSEIFER, 2008, p.264).

Nesse viés, destaca-se o entendimento de Michel Prieur (2011, p. 88), ao afirmar que o meio ambiente é uma política-valor em busca do bem-estar humano e animal, razão pela qual surge a necessidade de um progresso permanente, que tem como passo inicial a vedação de todas as regressões. Com efeito, mesmo que o direito ao meio ambiente seja consagrado em várias Constituições é, de forma paradoxal e reiterada. O autor destaca ainda que o 
Análise da aplicação do princípio da vedação de retrocesso ambiental pelo supremo tribunal... Eriberto Francisco Bevilaqua Marin • Giovani Martins De Araújo Mascarenhas

Direito ambiental deve entrar na categoria das regras jurídicas intangíveis e não revogáveis, em nome do interesse da humanidade.

Outros autores, a exemplo de Marcos André Bruxel Saes et. al. (2018), fazem um contraponto a essa compreensão sobre o princípio da vedação de retrocesso em matéria ambiental, defendida por Prieur, Fensterseifer, Sarlet e outros. Afirmam que a interpretação já exposta se trataria de uma "interpretação alargada" e que o mais correto seria a adoção da "interpretação ponderada" proposta. Para os autores, o princípio somente poderia ser aplicado em caso de revogação/alteração legislativa que aviltasse o núcleo essencial do direito tutelado. A aplicação somente se daria "em que realmente seu uso seja pertinente" e com o único escopo de proteger o núcleo mínimo existencial do direito cujo retrocesso seria discutido. Nesse sentido, propõem um princípio casuístico que se confunde com o mínimo existencial - que, conforme visto, constituiria apenas um dos elementos que devem ser considerados na sua aplicação. Nesse aspecto, a sua "pertinência" ou aplicação ao caso concreto podem configurar excessos de subjetivismos e de sua não aplicação diante de valores ou interpretações casuísticas.

Ao se adotar a interpretação mais aceita do princípio da vedação de retrocesso e de sua normatividade, alcança-se a compreensão de que o princípio impõe a proteção que já foi consagrada e não apenas ao núcleo mínimo existencial. Dessa forma, verifica-se uma afronta ao princípio da vedação ao retrocesso sempre que uma alteração legislativa diminui uma proteção anteriormente conferida ao meio ambiente, sem constituir, ao mesmo tempo, uma proteção correspondente que supra essa diminuição. Ao atuar como limite mínimo de proteção ambiental (não apenas ao mínimo existencial), o princípio ademaisimpõe a precípua tarefa-dever de progressiva realização dos direitos ambientais, pela qual se deve buscar o aprimoramento das condições normativas e fáticas para assegurar a efetividade do direito tutelado.

A vedação de retrocesso atua nas limitações que impõe ao legislador, pois não só proíbe a supressão de direitos já alcançados, como também obriga a busca de maior eficácia, proteção e 
Análise da aplicação do princípio da vedação de retrocesso ambiental pelo supremo tribunal... Eriberto Francisco Bevilaqua Marin • Giovani Martins De Araújo Mascarenhas

abrangência desses direitos. O legislador fica adstrito a uma única possibilidade quando promover qualquer alteração legislativa, ou seja, a de melhorar as condições propostas sem retrocessos. A orientação é buscar a melhoria e a majoração do direito fundamental ao meio ambiente, como dever proveniente do status de direito fundamental, merecedor de seu pleno gozo. Ingo Sarlet e Tiago Fensterseifer (2013, p. 294) destacam que o princípio da vedação de retrocesso traz uma dupla obrigação ao poder público na medida em que vincula a obrigação de "não piorar" as condições já existentes no ordenamento jurídico, amparadas pelo mínimo existencial, bem como de impor a obrigação de aprimorar as condições existentes.

Nesse desiderato, o Protocolo Adicional à Convenção Americana sobre Direitos Humanos em Matéria de Direitos Econômicos, Sociais e Culturais (1988), adotado em San Salvador, acrescenta e incorpora a compreensão sobre a abrangência do Direito ambiental. O texto do protocolo estabelece que "toda pessoa tem direito a viver em um meio ambiente sadio e a contar com os serviços públicos básicos" (art. 11.1), e destaca de forma a regular e impor que "os Estados-Partes promoverão a proteção e o melhoramento do meio ambiente" (art. 11.2).

Assim, as medidas vindouras no que se referemàs matérias ambientais, vinculadas ao princípio da proibição de retrocesso e de progressiva realização de seus objetivos, devem buscar medidas normativas e fáticas voltadas à tutela ambiental, como forma de proporcionar uma progressiva melhoria da qualidade ambiental e, consequentemente, da qualidade de vida (SARLET, FENSTERSEIFER, 2013, p. 296). 


\section{A criação das Áreas Rurais Consolidadas e as Ações de (In)Constitucionalidade propostas perante o Supremo Tribunal Federal}

A Lei n. ${ }^{\circ}$ 12.651, de 2012, que instituiu a Lei Florestal brasileira, representou uma grande alteração do cenário normativo florestal brasileiro e, por consequência, suscitou diversos questionamentos da comunidade jurídica e técnico-científica acerca da compatibilidade da nova lei com as disposições constitucionais implícitas ou expressas na Constituição de 1988. As controvérsias e questionamentos motivaram a interposição, por iniciativa do ProcuradorGeral da República, das ADIs n. ${ }^{\circ}$ 4901, 4902 e 4903, em 21 de janeiro de 2013; do Partido Socialismo e Liberdade (PSOL), da ADI n. ${ }^{\circ}$ 4937/DF, em 4 de abril de 2013; e do Partido Progressista (PP), da Ação Declaratória de Constitucionalidade (ADC) n. ${ }^{\circ} 42$, em 8 de abril de 2016. Estas ações, propostas perante o Supremo Tribunal Federal, tinham por objeto o posicionamento do Poder Judiciário acerca da constitucionalidade ou inconstitucionalidade de diversos dispositivos da referida lei.

As referidas ações questionam a constitucionalidade de diversos dispositivos contidos na Lei n. ${ }^{\circ} 12.651 / 2012$ sob a perspectiva de violação do princípio da vedação de retrocesso ambiental, dentre as quais se destaca a análise da criação das Áreas Rurais Consolidadas, indicadas nos arts. 59, 60 e 61-A da Lei n. ${ }^{\circ}$ 12.651/2012 (sem prejuízo dos dispositivos legais que integram sua aplicação). Das ações propostas, os arts. 59 e 60 foram objeto das ADIs n. ${ }^{\circ} 4.902$ e n. ${ }^{\circ} 4.937$ e da $A D C$ n. ${ }^{\circ}$ 42. Os referidos dispositivos, ao criarem as Áreas Rurais Consolidadas, tratam, talvez, da mais relevante alteração trazida pela norma florestal, sendo amplamente criticada em função de suposta ofensa, dentre outros aspectos, ao princípio da vedação de retrocesso em matéria ambiental (MILARÉ; MACHADO, p. 430).

O caput do art. 59, da Lei Florestal brasileira, dispõe sobre a implantação de Programas de Regularização Ambiental (PRAs) de 
Análise da aplicação do princípio da vedação de retrocesso ambiental pelo supremo tribunal... Eriberto Francisco Bevilaqua Marin • Giovani Martins De Araújo Mascarenhas

posses e propriedades rurais, com o objetivo de adequá-las aos termos do capítulo em que se insere para o uso das Áreas Rurais Consolidadas. Assim, a lei delega ao chefe do Poder Executivo (da União, Estados-membros e Distrito Federal) a responsabilidade de editar normas para regular os PRAs, em conformidade com as características específicas das regiões, por suas peculiaridades territoriais, climáticas, históricas, culturais, econômicas e sociais (art. 59 , § $\left.1^{\circ}\right)$.

Os $\S \S 4^{\circ}$ e $5^{\circ}$ do referido art. 59, que tratam da suspensão da punibilidade de determinados crimes ambientais e da suspensão da exigibilidade das sanções decorrentes de infrações administrativas, também foram objetos de questionamentos sobre a sua constitucionalidade. Os dispositivos determinam que o proprietário ou possuidor rural não poderá ser autuado por infrações, cometidas antes de 22 de julho de 2008, relativas à supressão irregular de vegetação em Áreas de Preservação Permanente ou Reservas Legais. As suspensões são condicionadas ao cumprimento do termo de compromisso de regularização ambiental, sendo que até a regulação específica dos termos desses programas, a punibilidade, também estará suspensa.

$\mathrm{O}$ art. 59 possui como objetivo o saneamento dos passivos ambientais e tem como meio apto a atingi-lo a vinculação à adesão ao Programa de Regularização Ambiental. 0 art. 60, em complemento ao disposto no art. 59, estatui que a assinatura de termo de compromisso para regularização de imóvel ou posse rural suspenderá a punibilidade dos crimes previstos nos arts. 38, 39 e 48 da Lei de Crimes Ambientais (BRASIL, 1998), que tratam sobre os danos causados à flora em áreas de preservação permanente ou dificultar a regeneração de florestas. Nos seus parágrafos, o art. 60 indica que o prazo prescricional de tais crimes ficará interrompido durante o período de suspensão da pretensão punitiva, extinguindo-se a punibilidade com a efetiva regularização.

A inovação legislativa não diz respeito somente à suspensão da punibilidade de infrações cometidas em Áreas de Preservação Permanente (APPs) e Reservas Legais (RLs), ou sobre os Programas 
Análise da aplicação do princípio da vedação de retrocesso ambiental pelo supremo tribunal... Eriberto Francisco Bevilaqua Marin • Giovani Martins De Araújo Mascarenhas

de Regularização Ambiental (PRAs) ou ao Cadastro Ambiental Rural (CAR), como procedimento necessário para adesão ao PRA. Essas ações já faziam parte do Programa do Governo Federal Mais Ambiente, criado pelo Decreto n. ${ }^{\circ} 7.029 / 2009$ e destinado à regularização ambiental de imóveis rurais (MILARÉ; AFFONSO, p. 423). Nesse aspecto, a inovação concerne na suspensão da punibilidade dos crimes, inclusive com a abrangência tanto da esfera administrativa, como da esfera penal.

Dos arts. 59 e 60 da Lei Florestal brasileira, verifica-se que o proprietário ou possuidor rural que tiver aderido ao Programa de Regularização Ambiental e estiver cumprindo com as obrigações impostas no termo de compromisso não poderá ser autuado por fatos ocorridos antes de 22 de julho de 2008, e, por consequência, terá suspensa a sua punibilidade. Caso seja descumprido o acordo, o prazo prescricional anterior à sua celebração será somado ao prazo posterior ao descumprimento, o que facilita a imposição de penalidade ao infrator.

Para Edis Milaré e Paulo Affonso Leme Machado (2013, p. 431), “o art. 59, § $4^{\circ}$ da Lei 12.651/2012 estabelece que quem tiver aderido ao PRA e estiver cumprindo todos os compromissos assumidos no termo, não poderá ser autuado por fatos ocorridos até 22/07/2008". Desse modo, segundo os autores (2013, p. 431 e s.), a punibilidade estará suspensa enquanto as obrigações estiverem sendo cumpridas para os que praticaram um dos delitos previstos na Lei 12.651/2012, que são dos arts. 38, 39 e 48 da Lei 9.605/1998, antes ou depois de 22 de julho de 2008, nos termos do art. 60 da nova Lei Florestal. Com efeito, se vierem a firmar Termo de Compromisso (TC) para a regularização do imóvel perante o órgão ambiental, por meio dos Programas de Regularização Ambiental de posses e propriedades rurais previstos no art. 59.

Não obstante a suspensão da punibilidade e a interrupção da prescrição, o $\S 5^{\circ}$ do art. 59 prevê a continuidade de uso das áreas de APP e RLs indevidamente suprimidas, desde que utilizadas em atividades rurais até 22 de julho de 2008, uma vez que essas áreas receberam respaldo do legislador e ganharam status de Áreas 
Análise da aplicação do princípio da vedação de retrocesso ambiental pelo supremo tribunal... Eriberto Francisco Bevilaqua Marin • Giovani Martins De Araújo Mascarenhas

Rurais Consolidadas. O marco temporal definido refere-se à promulgação do Decreto n. ${ }^{\circ} 6.514$, de 22 de julho de 2008, responsável por estabelecer regras específicas para as sanções administrativas relativas às infrações cometidas contra o meio ambiente.

Os questionamentos sobre a adequação constitucional do citado artigo referem-se aos benefícios concedidos aos proprietários ou possuidores rurais que aderirem ao PRA, tanto no que tange à suspensão da punibilidade de crimes, quanto naquilo que se refere à continuidade de uso de áreas protegidas consolidadas, na medida em que esse último constituiria violação aos institutos da APP e RLS.

As inovações legislativas, conforme alegado nas petições das Ações Diretas de Inconstitucionalidade (n. ${ }^{\circ}$ 4901, 4902, 4903 e 4937) e Ação Declaratória de Constitucionalidade (n. $\left.{ }^{\circ} 42\right)$, estariam em desacordo com a proteção do meio ambiente ao infringirem o correlato mínimo existencial ambiental, em razão da anistia aos crimes ambientais cometidos. Nessa lógica, além de retirar a proteção anteriormente prevista, as medidas constituem uma ofensa ao princípio de não retrocesso ambiental.

Por ocasião do julgamento das referidas ações, o Plenário do STF realizou audiência pública ${ }^{5}$ sobre o tema e admitiu nos autos dezoito amici curiae (amigos da Corte), e o relatório comum versou, em conjunto, a constitucionalidade de uma série de dispositivos da Lei n. ${ }^{\circ} 12.651 / 2012$, com as alterações promovidas pela Lei n. ${ }^{\circ} 12.727 / 2012$, cuja ementa do acórdão faz referência ao dever de proteção ambiental; ao disposto no art. 225 da Constituição de 1988; à necessidade de compatibilização com outros vetores constitucionais de igual hierarquia, a exemplo dos arts. $1^{\circ}$, inciso IV, $3^{\circ}$, incisos II e III, $5^{\circ}$, caput e inciso XXII, 170, caput e incisos II, V, VII E VIII, da Constituição; ao desenvolvimento sustentável e da justiça intergeracional; à alocação de recursos para atender as necessidades da geração atual; a escolha política e o controle judicial

\footnotetext{
5 A audiência pública foi realizada em 18 de abril de 2016, com a participação de 23 representantes da sociedade que, em grande parte, argumentavam que a Lei 12.651/2012 teria sido desenvolvida para atender a interesses de setores do agronegócio, com a mitigação das proteções ambientais já existentes com o escopo de facilitar a economia de extração de commodities, sobre a qual se tratou no item 2 do presente artigo.
} 
Análise da aplicação do princípio da vedação de retrocesso ambiental pelo supremo tribunal... Eriberto Francisco Bevilaqua Marin • Giovani Martins De Araújo Mascarenhas

de políticas públicas; à impossibilidade de violação do princípio democrático; o exame de racionalidade estreita; o respeito aos critérios de análise decisória empregados pelo formador de políticas públicas; à inviabilidade de alegação de "vedação ao retrocesso"; o novo código florestal; e às ações diretas de inconstitucionalidade e ação declaratória de constitucionalidade julgadas parcialmente procedentes (STF- Tribunal Pleno - ADC 42/DF, Divulgação: 12.08.2019; Publicação Dje-175 13.08.2019).

Na decisão, o Supremo Tribunal Federal conferiu uma interpretação conforme a Constituição para os $\S \S 4^{\circ}$ e $5^{\circ}$ do art. 59, bem como para o $\S 1^{\circ}$ do art. 60, da Lei n. ${ }^{\circ} 12.651 / 2012$, no julgamento da ADC e ADIs ${ }^{6}$. Desse modo, no decurso da execução dos termos de compromissos subscritos nos Programas de Regularização Ambiental, afasta-se o risco de decadência ou prescrição, seja dos ilícitos ambientais praticados antes de 22 de julho de 2008, seja das sanções dele decorrentes, aplicando-se extensivamente o disposto no $\S 1^{\circ}$ do art. 60 da Lei n. ${ }^{\circ} 12.651 / 2012$. Dessa forma, os questionamentos sobre a anistia e ocorrência da prescrição foram suplantados sob o argumento de que as Áreas Rurais Consolidadas funcionariam como um efetivo incentivo para que os proprietários e possuidores rurais aderissem aos Programas de Regularização Ambiental, o que conferiria, por consequência, uma maior proteção ao meio ambiente. Não haveria, assim, violação ao princípio da vedação de retrocesso ambiental, pois a diminuição de uma proteção anteriormente conferida (proteção a RLs e APPs) seria compensada pela necessidade de adesão ao Plano de Regularização Ambiental (PRA).

\footnotetext{
$\overline{6 \text { "xxiv) POR MAIORIA }}$, dar interpretação conforme a Constituição ao art. 59, §4 , do Código Florestal, de modo a afastar, no decurso da execução dos termos de compromissos subscritos nos programas de regularização ambiental, o risco de decadência ou prescrição, seja dos ilícitos ambientais praticados antes de 22.7.2008, seja das sanções deles decorrentes, aplicando-se extensivamente o disposto no $\S 1^{\circ}$ do art. 60 da Lei 12.651/2012, segundo o qual "a prescrição ficará interrompida durante o período de suspensão da pretensão punitiva", vencidos os Ministros Luiz Fux (Relator), Marco Aurélio, Edson Fachin, Roberto Barroso e Ricardo Lewandowski, e, em parte, o Ministro Gilmar Mendes; xxv) POR MAIORIA, dar interpretação conforme à Constituição ao art. 59, $\S 5^{\circ}$, de modo a afastar, no decurso da execução dos termos de compromissos subscritos nos programas de regularização ambiental, o risco de decadência ou prescrição, seja dos ilícitos ambientais praticados antes de 22.7.2008, seja das sanções deles decorrentes, aplicando-se extensivamente o disposto no § 1 o do art. 60 da Lei 12.651/2012, segundo o qual "a prescrição ficará interrompida durante o período de suspensão da pretensão punitiva", vencidos os Ministros Luiz Fux (Relator), Marco Aurélio, Edson Fachin, Roberto Barroso e Ricardo Lewandowski, e, em parte, o Ministro Gilmar Mendes; xxvi) POR MAIORIA, vencidos os Ministros Luiz Fux (Relator), Marco Aurélio, Roberto Barroso e Ricardo Lewandowski, reconhecer a constitucionalidade do art. 60 do Código Florestal."(STF, 2018, p. 23)
} 
Análise da aplicação do princípio da vedação de retrocesso ambiental pelo supremo tribunal... Eriberto Francisco Bevilaqua Marin • Giovani Martins De Araújo Mascarenhas

Apesar de existirem diversos pontos de divergência entre os votos proferidos pelos ministros do STF, responsáveis pelo julgamento das (in)constitucionalidades, e que permeiam o texto original da Lei n. ${ }^{0} 12.651 / 2012$, verificou-se que a aplicação do princípio da vedação de retrocesso foi utilizado como fundamento para dar supedâneo às suas decisões, seja para afastar o retrocesso ambiental suscitado ou apontar eventual inconstitucionalidade.

\section{O Supremo Tribunal Federal e aplicação do princípio da vedação de retrocesso em face das Áreas Rurais Consolidadas, instituídas na Lei Florestal brasileira}

Na decisão do STF, prevaleceu o entendimento predominante dos ministros do Supremo Tribunal Federal de que não haveria inconstitucionalidade a ser afastada, sob o argumento de uma possível ofensa ao princípio da vedação de retrocesso ambiental, nos artigos questionados que tratam sobre a criação de Áreas Rurais Consolidadas em Áreas de Preservação Permanente ou Reservas Legais. Apesar de ter sido citado em diversas passagens no acórdão e votos dos ministros, na decisão prevaleceu o entendimento de inviabilidade de alegação de vedação ao retrocesso ambiental.

No voto, o ministro relator Luiz Fux menciona que o princípio da vedação de retrocesso ambiental "não se sobrepõe ao princípio democrático no afã de transferir ao Judiciário funções inerentes aos Poderes Legislativo e Executivo, nem justifica afastar arranjos legais mais eficientes para o desenvolvimento sustentável do país como um todo" (2018, p. 6). Em seus fundamentos, a decisão refuta a aplicação automática da tese de vedação ao retrocesso para anular opções validamente eleitas pelo legislador. Sem entrar no mérito do retrocesso ambiental, a decisão pugna pela autocontenção do Judiciário diante de uma "transparência e a extensão do processo legislativo desenvolvido, que conferem legitimidade adicional ao produto da atividade do Congresso Nacional" (2018, p. 8). 
Análise da aplicação do princípio da vedação de retrocesso ambiental pelo supremo tribunal... Eriberto Francisco Bevilaqua Marin • Giovani Martins De Araújo Mascarenhas

Nessa linha de raciocínio, o ministro Gilmar Mendes (2018, p. 546), com fundamento no processo legislativo participativo e deferência às escolhas políticas consolidadas na Lei n. ${ }^{\circ}$ 12.651/2012, entende que as decisões dessa natureza somente podem ser revistas pelo STF "quando se tratar de inconstitucionalidade, cuja constatação não requeira profunda revisão das premissas fáticas e técnico-jurídicas adotadas na tomada da decisão legislativa". Para o ministro, "a revisão das premissas adotadas pelo Poder Legislativo na tomada de decisão em matéria de natureza técnico-científica encontra limites na capacidade institucional do STF, recomendando uma postura de autocontenção" (MENDES, 2018, p. 546).

No acórdão, o Ministro Luiz Fux (2018, p. 4) registra que "as políticas públicas ambientais devem conciliar-se com outros valores democraticamente eleitos pelos legisladores" e, nesse aspecto, os elegeu como sendo, dentre outros, o mercado de trabalho, o desenvolvimento social e o atendimento às necessidades básicas de consumo dos cidadãos. Em seguida, conclui que não é "adequado desqualificar determinada regra legal como contrária ao comando constitucional de defesa do meio ambiente (art. 225, caput, CRFB), ou mesmo sob ogenérico e subjetivorótulo de 'retrocesso ambiental', ignorando as diversas nuances que permeiam o processo decisório do legislador, democraticamente investido da função de apaziguar interesses conflitantes por meio de regras gerais e objetivas"(2018, p. 4).

Mais adiante (FUX, 2018, p. 50), argumenta que "a escolha de políticas públicas no âmbito do Direito Ambiental representa a difícil tarefa de acomodar a satisfação de diferentes valores relevantes em permanente tensão". Nessa linha, afirma que não se deve desprezar que a mesma Constituição protetora dos recursos ambientais do país também exorta o Estado brasileiro a garantir a livre iniciativa (artigos $1^{\circ}, \mathrm{IV}$, e 170), o desenvolvimento nacional (art. $\left.3^{\circ}, 11\right)$, a erradicar a pobreza e a marginalização e reduzir as desigualdades sociais e regionais (art. $3^{\circ}, \mathrm{III}$; art. 170, VII), a proteger a propriedade (art. $5^{\circ}$, caput e XXII; art. 170, II), a buscar o pleno 
Análise da aplicação do princípio da vedação de retrocesso ambiental pelo supremo tribunal... Eriberto Francisco Bevilaqua Marin • Giovani Martins De Araújo Mascarenhas

emprego (art. 170, VIII; art. $6^{\circ}$ ), a defender o consumidor (art. $5^{\circ}$, XXXIl; art. 170, V) etc. (FUX, 2018, p. 50).

Em outra passagem, o ministro relator Luiz Fux (2018, p. 61) salienta "que a revisão judicial das premissas empíricas que embasam determinada medida regulatória, quanto mais quando editada pelo legislador democrático, não pode ocorrer pela singela e arbitrária invocação de um suposto 'retrocesso' na defesa do meio ambiente". Em nova passagem sobre a vedação ao retrocesso, Fux (2018, p. 61) cita que os defensores da teoria "entendem existente um estado de inconstitucionalidade quando eliminada determinada norma infraconstitucional ou estrutura material essencial para a concretização mínima de um comando explícito da Carta Magna". Dessa forma, "qualquer tipo de reforma legislativa ou administrativa que possa causar decréscimo na satisfação de um dado valor constitucional seria ignorar um elemento básico da realidade: a escassez" (FUX, 2018, p. 62). Ao registrar que "a jurisprudência do Supremo Tribunal Federal, a propósito, demonstra deferência judicial ao planejamento estruturado pelos demais Poderes no que tange às políticas públicas ambientais", o ministro Fux (2018, p. 63-4), assim arremata:

\begin{abstract}
O engessamento das possibilidades de escolhas na formulação de políticas públicas, a impedir a redistribuição de recursos disponíveis entre as diversas finalidades carentes de satisfação na sociedade, em nome de uma suposta "vedação ao retrocesso" sem base no texto constitucional, viola o núcleo básico do princípio democrático e transfere indevidamente ao Judiciário funções inerentes aos Poderes Legislativo e Executivo. (...), ainda afasta arranjos mais eficientes para o desenvolvimento sustentável do país como um todo.
\end{abstract}

Para o ministro relator Luiz Fux (2018, p. 66), os "Tribunais não são a sede adequada para reverter o resultado do jogo democrático quando a vontade de certos grupos não for privilegiada pela lei, salvante as hipóteses de claro, específico e direto comando constitucional dirigido ao legislador ou administrador". 
Análise da aplicação do princípio da vedação de retrocesso ambiental pelo supremo tribunal... Eriberto Francisco Bevilaqua Marin • Giovani Martins De Araújo Mascarenhas

Por seu turno, o ministro Edson Fachin (2018, p. 383), em seu voto, cita o princípio constitucional implícito da proibição do retrocesso e declara a sua importância ao impedir a retirada de efetividade das normas constitucionais e por representar uma importante exigência de vinculação do legislador ao núcleo essencial dos direitos fundamentais. Apesar disso, afirma que o princípio "não pode ser compreendido como vedação absoluta a escolhas legislativas cujos propósitos podem ser considerados razoáveis para a garantia e a efetivação de interesses condicionais relevantes", e interpretá-lo de outra forma impõe um limite excessivo à função legislativa e o tornaria incompatível com o princípio democrático (FACHIN, 2018, p. 383). Não obstante considerar um princípio implícito, entende que "onde se obteve um determinado avanço social não se pode retroceder sem que se coloque no lugar alguma coisa que seja constitucionalmente aceitável e não implique em um déficit significativo de proteção de um determinado bem social". Do contrário, seria dificultar "uma mudança legislativa que eventualmente precisasse acompanhar a evolução dos fatos e da própria realidade social" (FACHIN, 2018, p. 383).

A ministra Rosa Weber (2018, p. 446) entende "que eventual medida restritiva do direito fundamental ao meio ambiente sadio e equilibrado deverá encontrar respaldo na própria ordem constitucional, como nas hipóteses de determinadas atividades econômicas", que se justifica a partir do emprego do postulado normativo da proporcionalidade, como técnica de tutela do princípio da vedação do retrocesso em matéria ambiental. E a veiculação de qualquer medida restritiva somente deve ocorrer por meio de uma lei, em sentido formal e material.

Com fundamento em lição de Canotilho, o ministro Dias Toffoli (2018, p. 595) afirma que não se pode falar de retrocesso quando forem adotadas medidas compensatórias adequadas para intervenções lesivas no meio ambiente, sobretudo quando essas medidas contribuíram para uma clara melhoria da situação ambiental, bem como justifica que a vedação de retrocesso não tem natureza absoluta em face dos limites impostos pelo princípio democrático, 
Análise da aplicação do princípio da vedação de retrocesso ambiental pelo supremo tribunal... Eriberto Francisco Bevilaqua Marin • Giovani Martins De Araújo Mascarenhas

que recomenda deferência às opções legislativas contidas na lei questionada, e pela capacidade institucional da Corte. Ademais, afirma que "não se pode interpretar o princípio da vedação de retrocesso de modo a petrificar as normas infraconstitucionais anteriores garantidoras de determinado padrão de proteção ambiental" (TOFFOLI, 2018, p. 595). Em complemento, afirma que a configuração do retrocesso deverá ser aferida caso a caso e com avaliação se houve a violação do núcleo essencial da norma constitucional de tutela do meio ambiente.

O ministro Marco Aurélio, em seu voto (STF, 2018, p. 168), registra que a formação de Áreas Rurais Consolidadas em áreas suprimidas antes de 22 de julho de 2008 constitui um regime específico de transição, que teria o escopo de resguardar a segurança jurídica dos proprietários rurais. O ministro(2018, p. 168) registra que, para auferir marco temporal capaz de funcionar como um marco transitório entre os regimes de proteção ambiental, seria necessário o respaldo em fundamentos técnicos e científicos. Apesar dessa necessidade que aponta, a Lei Florestal adota critério aleatório, utilizando-se do início da vigência do Decreto n. ${ }^{\circ}$ 6.514 , de 22 de julho de 2008. Para o ministro, o marco de transição "revela-se arbitrário, sendo inviável dele extrair fundamento plausível relacionado à tutela do meio ambiente ou promoção da segurança jurídica" (STF, 2018, p. 177). Ocorre que, por inexistir um marco histórico técnico e justificável, a data eleita pelo legislador foi mantida.

Em relação ao descumprimento do princípio da vedação de retrocesso em matéria de direitos fundamentais, o ministro Celso de Mello (2018, p. 630-1), ao proferir seu voto, rememorou as lições de Larissa Ambrosano Packer ao expor que a fundamentação de todas as ações encontra-se na infringência do princípio da vedação de retrocesso em matéria de direitos fundamentais por diminuir o grau de proteção ao meio ambiente. Apontou, outrossim, que a ofensa ao princípio da vedação de retrocesso estaria ligada também à violação do princípio da proporcionalidade, em sua vertente de vedação da proteção deficiente, ao passo que, como 
Análise da aplicação do princípio da vedação de retrocesso ambiental pelo supremo tribunal... Eriberto Francisco Bevilaqua Marin • Giovani Martins De Araújo Mascarenhas

conformador de direito fundamental, vincula o legislador a não restringir ou prejudicar o direito resguardado, razão pela qual cita que as ações expõem que a maioria dos dispositivos questionados "entra em rota de colisão com o regime jurídico-constitucional" no que tange às áreas e espaços territoriais protegidos, notadamente com mandamentos explícitos e vinculantes que impõem deveres fundamentais ao poder público e à coletividade, assim enunciados (MELLO, 2018, p. 631):

i) vedação que tais espaços sejam utilizados de forma que comprometa os atributos que justificam sua proteção (art. 225, § $1^{\circ}$, III); ii) dever de preservar e restaurar processos ecológicos essenciais (art. 225, $\S 1^{\circ}, \mathrm{l}$ ); iii) dever de proteger a diversidade e integridade do patrimônio genético (art. 225, II); iv) dever de proteger fauna e flora, com a proibição de práticas que coloquem em risco sua função (art. 225, § $1^{\circ}, \mathrm{VII}$ ); v) dever de cumprir com elemento ecológico da posse ou propriedade - função socioambiental da propriedade.

No entanto, com fundamento na jurisprudência do Supremo Tribunal Federal, Celso de Mello (2018, p. 662), em seu voto, "demonstra deferência judicial ao planejamento estruturado pelos demais Poderes no que tange às políticas públicas ambientais", em detrimento da aplicação do princípio da vedação de retrocesso ambiental.

Em outra linha de entendimento, para o ministro Luís Roberto Barroso (STF, 2018, p. 430), o princípio constitucional implícito da proibição do retrocesso "impede a retirada de efetividade das normas constitucionais e representa uma importante exigência de vinculação do legislador ao núcleo essencial dos direitos fundamentais". Todavia, considera que o princípio não é absoluto diante da atuação do legislador, sob pena de limitação ao princípio democrático e de evolução dos fatos e da própria realidade social. Nesse sentido, em caso de se obter um determinado avanço social, "não se pode retroceder sem que se coloque no lugar alguma coisa que 
Análise da aplicação do princípio da vedação de retrocesso ambiental pelo supremo tribunal... Eriberto Francisco Bevilaqua Marin • Giovani Martins De Araújo Mascarenhas

seja constitucionalmente aceitável e não implique em um déficit significativo de proteção de um determinado bem social" (2018, p. 430). Em relação à criação das Áreas Rurais Consolidadas, o ministro Luís Roberto Barroso (STF, 2018, p. 431) considerou que é medida permeada por grande desproporcionalidade, visto que "impõe severo ônus ao meio ambiente, mas gera benefícios ínfimos em razão da estabilização de situações jurídicas consolidadas".

Em seu voto vista, a ministra Cármen Lúcia (STF, 2018, p. 232) reconhece o princípio constitucional implícito da vedação de retrocesso ambiental como parâmetro de controle de constitucionalidade, para se avaliar a sua proporcionalidade e seu respeito ao núcleo essencial dos direitos socioambientais, sob pena de prejuízos às presentes e futuras gerações. Contudo, afirma não ser compatível com a Constituição da República, portanto, "a superação da legislação ambiental, sem que sejam simultaneamente editadas medidas que compensem o impacto ambiental causado por normas mais permissivas".

Na decisão do STF, observa-se que, no referido acórdão, em diversas passagens os ministros citam o princípio da vedação de retrocesso ambiental com diferentes interpretações.Para o ministro Luiz Fux, a vedação ao retrocesso é indicada como um valor (axiológico) e não como um princípio constitucional implícito, portanto normativo (deontológico) e aplicável. Em outro sentido,a proibição do retrocesso é princípio constitucional implícito e fundamenta-se no "princípio do Estado (Democrático e Social) de Direito, o princípio da dignidade da pessoa humana, o princípio da máxima eficácia e efetividade das normas definidoras de direitos fundamentais, o princípio da segurança jurídica e seus desdobramentos, o dever de progressividade em matéria de direitos sociais, econômicos, culturais e ambientais (DESCA)" (SARLET; FENSTERSEIFER; 2017. p. 302). Indicado como um direito individual e cláusula pétrea, o princípio constitucional implícito da vedação de retrocesso ambiental é destaque não apenas na Constituição, mas nos tratados internacionais, a exemplo dos arts. $2^{\circ}$ e 12 do Pacto Internacional sobre Direitos Econômicos, Sociais e Culturais - PIDESC (Decreto n. ${ }^{\circ}$ 
Análise da aplicação do princípio da vedação de retrocesso ambiental pelo supremo tribunal... Eriberto Francisco Bevilaqua Marin • Giovani Martins De Araújo Mascarenhas

591/1992), dos arts. $1^{\circ}$ e 11 do Protocolo de São Salvador (Decreto n. $\left.{ }^{\circ} 3.321 / 1999\right) ;$ do documento final da Conferência Rio+20 e do Estatuto do Rio Uruguai, portanto, de caráter normativo, devendo ser observado e aplicado pelos poderes públicos.

A aplicação do princípio da vedação de retrocesso deixa a desejar no cenário legislativo-jurídico brasileiro. O legislador vincula-se à observância ao princípio da vedação de retrocesso em promover alteração legislativa que promova a manutenção e meIhoria das condições propostas ao meio ambiente, como forma de proporcionar uma progressiva melhoria da qualidade ambiental e, consequentemente, da qualidade de vida. Em sentido contrário, a exemplo da decisão do STF de autocontenção judicial em face da decisão judicial, estar-se-á diminuindo ou retrocedendo na proteção ambiental.

Insta observar que, na decisão, o STF adota uma visão antropocêntrica na medida em que os recursos naturais devem ser protegidos, porém em benefício do homem. Os fundamentos de não aplicação do princípio justificam-se em razão de supostos interesses econômicos e valores indicados, a exemplo do mercado de trabalho, desenvolvimento social, atendimento às necessidades básicas de consumo dos cidadãos etc. Ou de outras normas dispostas na Constituição em que exorta o Estado brasileiro a garantir a livre iniciativa (artigos $1^{\circ}$, IV, e 170), o desenvolvimento nacional (art. $\left.3^{\circ}, \mathrm{II}\right)$, a erradicar a pobreza e a marginalização e reduzir as desigualdades sociais e regionais (art. $3^{\circ}$, III; art. 170, VII), a proteger a propriedade (art. $5^{\circ}$, caput e XXII; art. 170, II), a buscar o pleno emprego (art. 170, VIII; art. $6^{\circ}$ ), a defender o consumidor (art. $5^{\circ}$, XXXII; art. 170, V) etc.

Nesse aspecto, as origens da relação desenvolvimento e proteção ambiental podem ser encontradas nas décadas de 1940 e 1950, quando os Estados começaram a reconhecer e tomar medidas para mitigar o impacto das atividades humanas no meio ambiente. No pós-segunda guerra mundial (1939-1945), a preocupação com os efeitos destrutivos da guerra, a destruição das florestas e impacto da diminuição dos recursos naturais, dos efeitos 
Análise da aplicação do princípio da vedação de retrocesso ambiental pelo supremo tribunal... Eriberto Francisco Bevilaqua Marin • Giovani Martins De Araújo Mascarenhas

da poluição no desenvolvimento humano e na qualidade de vida resultou na resolução da ONU, de 1968, que convocou a Conferência das Nações Unidas sobre o Meio Ambiente Humano, realizada em Estocolmo, Suécia, no ano de 1972. Na conferência, o debate se polarizou entre os interesses dos países em desenvolvimento e os países desenvolvidos e deu origem a duas visões ou preocupações em relação à proteção ambiental e desenvolvimento ambiental. Desde então, o desenvolvimento, que fora pautado pelos países em desenvolvimento, e a proteção ambiental tornaram-se interesses em aparente conflito nos objetivos de preservação ambiental.

As preocupações com o desenvolvimento humano no discurso ambiental deu origem ao discurso antropocêntrico na medida em que a proteção ambiental passou a ser mitigada na presença das necessidades humanas e de seu desenvolvimento socioeconômico relacionado à produção de alimentos e bens de consumo, pobreza, desigualdades sociais e regionais, desemprego, saneamento básico etc., como problemas graves enfrentados pelas pessoas e pelo planeta. Apesar disso, no aparente conflito ou não, em face de uma interdependência lastreada no desenvolvimento sustentável, os interesses têm sido dicotômicos, na medida em que essa visão tem sido destaque das legislações para um desenvolvimento sustentável baseado em necessidades humanas, a exemplo da Constituição de 1988 e da decisão do STF nas referidas ações de inconstitucionalidades, que tiveram por objeto a Lei n. ${ }^{\circ} 12.561 / 2012$. $O$ desenvolvimentismo antropocêntrico tem prevalecido em face de uma efetiva proteção ecocêntrica (centrada na natureza com igualdade entre seres bióticos e abióticos). Na balança, as demandas humanas têm prevalecido diante da proteção ambiental, com impactos de degradação irreparáveis. Nesse processo, o desenvolvimento autodestrutivo tem contribuído, de forma significativa, no esgotamento dos recursos naturais, de degradação e poluição ambiental, com efeitos para todos os seres vivos do planeta, inclusive de sua sobrevivência.

Em nova visão, o meio ambiente não pode ser apenas um recurso de gozo e fruição pelos humanos em seus objetivos de 
Análise da aplicação do princípio da vedação de retrocesso ambiental pelo supremo tribunal... Eriberto Francisco Bevilaqua Marin • Giovani Martins De Araújo Mascarenhas

desenvolvimento e destruição ambiental. Ao contrário, em nova ressignificação, o meio ambiente deve ser protegido e respeitado, com a imposição jurídico-constitucional de vedação ao retrocesso ambiental, mesmo porque a pobreza, o desemprego, o consumo, as desigualdades sociais e regionais, dentre outros aspectos, não serão resolvidos com a degradação e poluição ambiental. Essa mudança de entendimento resulta na compreensão da indispensabilidade de uma proteção jurídica integrada ao meio ambiente. Todavia, encontra resistência (como em outros momentos na história) e entrave pela prevalência do viés econômico e social sobre os aspectos ambientais.

Até agora, o desenvolvimento das necessidades humanas multiplicou-se e desequilibrou a equação ambiental (BRIGTHON, 2016, p.232) e, nesse entendimento, se a agenda focar a implantação de imperativos ambientais em políticas de desenvolvimento, o efeito somente será efetivo se houver uma vedação expressa a qualquer retrocesso ambiental. Nesse aspecto, o imperativo da vedação ao retrocesso ambiental deve prevalecer na regulação e decisões públicas e privadas, como forma de equilibrar o "enquadramento antropocêntrico de preocupações ambientais" (BRIGTHON, 2016, p. 233).

A decisão do STF, com fundamento em preocupações sociais e econômicas e na autocontenção judicial, não levou em conta o princípio de vedação ao retrocesso ambiental e os impactos da proteção ambiental diante da criação das Áreas Rurais Consolidadas. A utilização de critérios suplementares apenas funcionou de subterfúgio para um julgamento de uma lei que não observa o princípio da vedação de retrocesso, que efetivamente diminuiu a proteção anteriormente garantida à natureza.

Na decisão, não se almejou o equilíbrio, seja por pender para o desenvolvimento das necessidades humanas, ou porque preferiu, como é a jurisprudência dominante da Corte Suprema, respeitar a decisão do legislador em matéria ambiental. Na "tensão de supostos valores", como expresso no voto do ministro relator Luiz Fux, prevaleceu o desenvolvimento, centrado em necessida- 
Análise da aplicação do princípio da vedação de retrocesso ambiental pelo supremo tribunal... Eriberto Francisco Bevilaqua Marin • Giovani Martins De Araújo Mascarenhas

des humanas, em detrimento da proteção ambiental. Proteção e desenvolvimento ambiental podem, em algumas situações, se apresentar como interesses que não estão em conflito entre si ou que os interesses se equilibram em conceitos de sustentabilidade, porém, quando apresentados em valores contrapostos, como foi o caso da decisão do STF, o desenvolvimento se sobrepôs em relação à proteção ambiental. Em algum momento, quiçá pelas futuras gerações, em razão das condições ambientais agravadas, o pêndulo recairá no foco da proteção ambiental em detrimento da atual dominância de um desenvolvimento destrutivo e falseado em argumentos de supostos benefícios humanos a serem protegidos, de mercado de trabalho, progresso econômico, extração, produção de alimentos e bens, exportação, consumo, pobreza etc., contudo, sem a identificação de seus atores e interesses.

\section{Considerações Finais}

Na última década, no contexto brasileiro, a legislação e as políticas públicas têm sido objeto de constantes flexibilizações, inclusive com questionamentos sobre sua adequação à Constituição de 1988 e de retrocessos na proteção ambiental. Dentre as flexibilizações, estão os arts. 59 e 60 da Lei Florestal brasileira, de 2012, que foram questionados perante o Supremo Tribunal Federal, por meio de ações diretas de (in)constitucionalidades, por afrontarem dispositivos constitucionais e o princípio da vedação de retrocesso ambiental.

Nesse caso, insere-se a análise da vedação de retrocesso, como princípio constitucional implícito, que visa a assegurar um nível elevado de proteção ao meio ambiente, bem como de seu desdobramento no dever de progressividade da proteção. $\mathrm{Na}$ análise realizada sobre o modo de aplicação teórico-normativa do princípio da vedação ao retrocesso, em casos práticos, sobressai a indispensabilidade de utilização de critérios complementares de avaliação para se decidir sobre eventual violação do princípio. 
Análise da aplicação do princípio da vedação de retrocesso ambiental pelo supremo tribunal... Eriberto Francisco Bevilaqua Marin • Giovani Martins De Araújo Mascarenhas

Na decisão proferida pelo Supremo Tribunal Federal, especificamente em relação aos arts. 59 e 60 da Lei Florestal, que tratam das Áreas Rurais Consolidadas, em sede de ações que questionavam a sua (in)constitucionalidade, verifica-se que o princípio da vedação de retrocesso foi efetivamente analisado nos fundamentos da decisão nas considerações dos ministros em seus votos, contudo sem a sua aplicação, com exceção do Ministro Luís Roberto Barroso, que fundamentou para considerar uma ofensa ao princípio da vedação ao retrocesso ambiental. Assim, tanto o legislador como o juiz constitucional não levaram em conta o princípio da vedação de retrocesso. O legislador se utilizou de audiências públicas e debates para justificar os interesses de criação das Áreas Rurais Consolidadas, como forma de manutenção de uma situação de destruição do meio ambiente. Já o julgador, sem análise de adequabilidade, utilizou-se de valores baseados em necessidades humanas, de forma discricionária, e fundamentada na decisão do legislador em detrimento da proteção ambiental, e decidiu pela inviabilidade de alegação de "vedação ao retrocesso". A vedação ao retrocesso, pelo relator considerada um valor, foi desconsiderada pela maioria do plenário em razão de uma autocontenção judicial.

As justificativas valorativas do legislador apenas funcionaram como subterfúgio para um julgamento de uma lei que ofende o princípio da vedação de retrocesso, que efetivamente diminuiu a proteção anteriormente garantida à natureza. A não observância ou ineficácia da lei anterior serviu como justificativa para ilegalidades cometidas e simboliza o discurso do "progresso" e do "desenvolvimento" travestido de razões jurídicas. Dessa forma, garantiu-se a sua exploração (mesmo que realizada em desconformidade com a lei em vigor) em detrimento da inarredável necessidade de proteção ambiental.

A atuação e justificativas do legislador e do julgador notabilizam um estímulo ao retrocesso ambiental, de flexibilização da regulação e de seus avanços, o que representa um alerta para a sociedade brasileira e mundial. O princípio da vedação de retrocesso ambiental é imprescindível e deve ser observado e respeitado, 
Análise da aplicação do princípio da vedação de retrocesso ambiental pelo supremo tribunal... Eriberto Francisco Bevilaqua Marin • Giovani Martins De Araújo Mascarenhas

em atenção à proteção ambiental e, com efeito, à dignidade humana e à garantia constitucional de um meio ambiente saudável para toda a coletividade. Nesse contexto, ressalta-se que o art. 225 da Constituição Federal dispõe que o dever de proteção do meio ambiente é comum ao poder público e à coletividade, sendo que o princípio da vedação de retrocesso apresenta-se também oponível aos particulares, que, por sua vez, mesmo diante de alteração legislativa prejudicial, devem utilizar os padrões mais benéficos ao meio ambiente em suas atividades.

\section{Referências}

ALEXY, Robert. A teoria dos direitos fundamentais. São Paulo: Malheiros, 2008.

ALIER, Juan Martínez. O ecologismo dos pobres. Raega-O Espaço Geográfico em Análise, v. 1, 1997.

ARAÚJO, Luciane Martins de. Desenvolvimento sustentável: estudo de impacto ambiental e estudo de impacto de vizinhança. Curitiba: Letra da Lei, 2008.

ARAÚJO, Luciane Martins de. Constituição verde, e agora? Fragmentos de cultura. PUC Goiás. Disponível em: <http://seer. pucgoias.edu.br/index.php/fragmentos/article/view/2760>. Acesso em 22 fev 2018.

BRASIL. Lei $n .^{\circ}$ 4.771, de 15 de setembro de 1965. Disponível em: <http://www.planalto.gov.br/Ccivil_03/Leis/L4771.htm>. Acesso em: 09 mar 2018.

BRASIL. Constituição da República Federativa do Brasil de 1988. Disponível em: <http://www.planalto.gov.br/ccivil_03/ Constituicao/Constituiçao.htm>. Acesso em 09 mar 2018.

BRASIL. Lei n. ${ }^{\circ}$ 12.651, de 25 de maio de 2012. Disponível em: <http://www.planalto.gov.br/ccivil_03/_ato2011-2014/2012/lei/ 112651.htm>. Acesso em: 27 fev 2018. 
Análise da aplicação do princípio da vedação de retrocesso ambiental pelo supremo tribunal... Eriberto Francisco Bevilaqua Marin • Giovani Martins De Araújo Mascarenhas

BRIGHTON, Claire. Unlikely bedfellows: the evolution of the relationship between environmental protection and development. International and comparative law quarterly, n. ${ }^{0}$, Vol. 66, Jan./2017, University of Cambridge. Cambridge: Reino Unido, p. 209 - 234. In: https://dialnet.unirioja.es/ejemplar/465817, DOI:10.1017/S002058931600052X.

CANOTILHO, José Joaquim Gomes. Estado constitucional ecológico e democracia sustentada. In: Heline Sivini; LEITE, José Rubens Morato (Orgs.). Estado de Direito ambiental: tendências: aspectos constitucionais e diagnósticos, Rio de Janeiro: Forense Universitária, 2004, p. 3-16.

CONFERÊNCIA DAS NAÇÕES UNIDAS SOBRE DESENVOLVIMENTO SUSTENTÁVEL (CNUDS). Sobre a Rio+20. Disponível em: <http:// www.rio20.gov.br/sobre_a_rio_mais_20.html>. Acesso em 09 set 2017.

FENSTERSEIFER, Tiago. Direitos fundamentais e proteção do ambiente: a dimensão ecológica da dignidade humana no marco jurídico-constitucional do Estado Socioambiental de Direito. Porto Alegre: Livraria do Advogado, 2008.

GRANZIERA, Maria Luiza Machado. Direito ambiental. 2. ed. São Paulo: Atlas, 2011.

LEITE, Icaro Demarchi Araújo. O Direito Internacional do meio ambiente e a aplicação de seus princípios e de suas normas pela empresa. 2011. Dissertação (Mestrado em Direito) Universidade de São Paulo, SP, 2011.

MACHADO, Paulo Affonso Leme. Legislação florestal (Lei 12.651/2012), competência e licenciamento ambiental (Lei Complementar 140/2011). São Paulo: Malheiros, 2012.

MACHADO, Paulo Affonso Leme. Direito ambiental brasileiro. 25. ed. São Paulo: Malheiros, 2017. 
MILARÉ, Edis. Direito do ambiente: doutrina, prática e jurisprudência, glossário. 2. ed. São Paulo: Revista dos Tribunais, 2001.

MILARÉ, Edis; MACHADO, Paulo Affonso Leme (orgs.). Novo Código Florestal. 2 ed. São Paulo: Revista dos Tribunais, 2013.

MORIN, Edgar. $O$ método 1. A natureza da natureza. Tradução Ilana Heineberg. Porto Alegre: Sulina, 2002.

de OLIVEIRA, Ariovaldo Umbelino. Os agrocombustíveis e a produção de alimentos. 2009. Disponível em: < http:// observatoriogeograficoamericalatina.org.mx/egal12/ Geografiasocioeconomica/Geografiaagricola/25.pdf>. Acesso aos 03 jul 2020.

PRIEUR, Michel. Droit de l'environnement. 6. ed. Paris: Dalloz, 2011.

SAES, Marcos André Bruxel; GULIN, Gleyse; TONON NETO, Nelson. $O$ princípio da proibição do retrocesso e o licenciamento ambiental. Disponível em: <http://www.saesadvogados.com.br/2018/01/10/o-principio-da-proibicao-do-retrocesso-e-o-licenciamento-ambiental/>. Acesso em: 28 de setembro de 2019.

SARLET, Ingo Wolfgang; FENSTERSEIFER, Tiago. Direito constitucional ambiental. 3. ed. São Paulo: Revista dos Tribunais, 2013.

\section{SUPREMO TRIBUNAL FEDERAL. Ação Declaratória de} Constitucionalidade $\mathbf{n} .^{\circ}$ 42.Disponível em:https://portal.stf.jus. br/processos/downloadPeca.asp?id=15340792543\&ext=.pdfAcesso em: 13 maio 2018.

SUPREMO TRIBUNAL FEDERAL. Ação Direta de Inconstitucionalidade $\mathbf{n} .^{\circ}$ 4901. Disponível em: <http:// redir.stf.jus.br/estfvisualizadorpub/jsp/consultarprocessoeletronico/ConsultarProcesso Eletronico.jsf?seqobjetoincidente $=4355097>$ Acesso em: 13 maio 2018. 
SUPREMO TRIBUNAL FEDERAL. Ação Direta de

Inconstitucionalidade $\mathbf{n} .^{\circ}$ 4902. Disponível em: <http://redir. stf.jus.br/estfvisualizadorpub/jsp/consultarprocessoeletronico/ ConsultarProcesso Eletronico.jsf?seqobjetoincidente $=4355128>$ Acesso em 13 maio 2018.

SUPREMO TRIBUNAL FEDERAL. Ação Direta de Inconstitucionalidade $\mathbf{n} .^{\circ}$ 4903. Disponível em: <http://redir. stf.jus.br/estfvisualizadorpub/jsp/consultarprocessoeletronico/ ConsultarProcesso Eletronico.jsf?seqobjetoincidente $=4355144>$ Acesso em: 13 maio 2018.

SUPREMO TRIBUNAL FEDERAL. Ação Direta de Inconstitucionalidade $\mathbf{n} .^{\circ}$ 4937. Disponível em: <http:// redir.stf.jus.br/estfvisualizadorpub/jsp/consultarprocessoeletronico/ConsultarProcessoEl etronico.jsf?seqobjetoincidente=4388129 >Acesso em: 13 maio 2018.

TRENNEPOHL, Terence Dorneles. Manual de Direito ambiental. São Paulo: Saraiva, 2010. 